\title{
EKSPRESI PROTEIN COATDAN MRNA VIRAL NERVOUS NECROSIS YANG DIKENDALIKAN OLEH PROMOTER $\beta$-AKTIN IKAN MEDAKA DAN KERATIN IKAN FLOUNDER JEPANG
}

\author{
Wiwien Mukti Andriyani*), Sri Murtini ${ }^{* * 4}$, Alimuddin ${ }^{* *}$, dan \\ I.W. Teguh Wibawan ${ }^{* *}$ \\ *) Balai Budidaya Air Payau \\ Jl. Raya Pecaron, Po. Box. 5 Panarukan, Situbondo, Jawa Timur 68351 \\ E-mail:wiwinmukti@gmail.com \\ *) Departemen Budidaya Perairan, Fakultas Perikanan dan IImu Kelautan, IPB \\ Jl. Rasamala, Kampus IPB Darmaga, Bogor 16680 \\ **) Departemen IImu Penyakit Hewan dan Kesmavet, Fakultas Kedokteran Hewan, IPB \\ Jl. Agatis, Kampus IPB Darmaga, Bogor 16680
}

(Naskah diterima: 2 Januari 2014; Disetujui publikasi: 28 Maret 2014)

\begin{abstract}
ABSTRAK
Kemampuan promoter dalam mengatur ekspresi gen penyandi protein imunogenik sangat menentukan efikasi suatu vaksin DNA. Penelitian ini bertujuan untuk mengukur tingkat ekspresi protein dan mRNA RNA2 penyandi coat protein (CP) virus viral nervous necrosis (VNN) yang dikendalikan oleh dua promoter berbeda, yaitu promoter $\beta$-aktin ikan medaka (mBA), dan keratin ikan flounder Jepang (JfKer). Uji ekspresi CP dilakukan menggunakan embrio ikan lele dumbo (Clarias sp.) sebagai model, sedangkan analisis mRNA dilakukan menggunakan ikan kerapu tikus. Konstruksi vektor ekspresi pmBA-CP dan pJKer- $\mathrm{CP}$ dengan konsentrasi $50 \mathrm{ng} / \mu \mathrm{L} \mathrm{KCl} 1 \mathrm{M}$ disuntikkan ke embrio ikan lele dumbo fase 1-2 sel. Sebanyak 30 embrio ikan lele dumbo diambil pada jam ke-6, 8, 10 , 12,14 , dan 16 pascainjeksi untuk analisis protein. Hasil SDS-PAGE menunjukkan adanya protein berukuran sekitar $42 \mathrm{kDa}$, dan analisis western blot menggunakan antibodi (Ab) poliklonal anti-VNN membuktikan bahwa protein tersebut adalah CP. Keberhasilan deteksi protein spesifik menggunakan $\mathrm{Ab}$ anti-VNN tersebut menunjukkan bahwa embrio ikan lele dapat digunakan untuk menguji potensi produksi protein imunogenik yang dikendalikan oleh promoter berbeda. Pengujian ini juga menunjukkan bahwa, aktivitas promoter mBA lebih tinggi daripada promoter JfKer, sehingga uji ekspresi mRNA dilakukan menggunakan konstruksi pmBA-CP. Benih ikan kerapu tikus (panjang badan sekitar $5 \mathrm{~cm}$ ) diinjeksi dengan pmBA-CP secara intramuskular dengan dosis $12,5 \mathrm{\mu g}$ /ekor. Total RNA diekstraksi dari daging pada waktu 6, 12, dan 24 jam pascainjeksi. Hasil RT-PCR menunjukkan adanya ekspresi mRNA CP pada 24 jam pascainjeksi. Hal tersebut menunjukkan bahwa promotor mBA aktif mengendalikan ekspresi CP pada ikan kerapu tikus, dan pmBA-CP berpotensi digunakan sebagai vaksin DNA untuk menginduksi kekebalan ikan kerapu terhadap infeksi VNN.
\end{abstract}

KATA KUNCl: protein coat, mRNA, viral nervous necrosis, promoter

ABSTRACT: The MRNA and coat protein expression of Viral Nervous Necrosis driven by Japanese medaka $\beta$-actin and keratin promoters. By: Wiwien Mukti Andriyani, Sri Murtini, Alimuddin, and I.W. Teguh Wibawan

The efficacy of a DNA vaccine is determined by the capability of the promoter to regulate the expression of genes encoding immunogenic proteins. The aims of this 
study were to quantify the level of protein expression and mRNA encoding viral nervous necrosis (VNN) RNA2 coat protein (CP) driven by two different promoters, namely $\beta$-actin promoter of medaka fish (MBA) and keratin promoter of Japanese flounder (JfKer). The catfish (Clarias sp.) embryo was used as a model to evaluate protein expression level, while the fish used for MRNA analysis was humpback grouper. Construction of pmBA-CP and pjKer-CP expression vector with $50 \mathrm{ng} / \mathrm{mL} 1 \mathrm{M} \mathrm{KCl}$ concentration was injected into the catfish embryos at 1-2 cell stage. A total of 30 embryos were harvested at 6, 8, 10, 12, 14, and 16 hours after injected for protein analysis. SDS-PAGE results showed a 42-kDa protein band, and the western blot analysis using polyclonal $A b$ anti-VNN proved that the protein was CP. The successful detection of specific proteins using anti-Ab VNN indicated that catfish embryo could be used to test the potential of the immunogenic protein expression controlled by different promoter. The results also showed that $m B A$ promoter activity was higher than the JfKer promoter. Thus, analysis of mRNA expression level was performed using pmBA$C P$ construct. The humpback grouper juveniles (5 cm body length) were injected with pmBA-CP intramuscularly at a dose of $12.5 \mathrm{\mu g} /$ fish. Total RNA was extracted from the fish flesh at 6, 12, and 24 hours post injection (hpi). RT-PCR analysis showed CP MRNA expression at $24 \mathrm{hpi}$. It was shown that the MBA promoter was active to control the $C P$ expression in humpback grouper, and pmBA-CP could potentially be used as a DNA vaccine to induce immunity of humpback grouper against VNN infection.

\section{KEYWORDS: coat protein, MRNA, viral nervous necrosis, promoter}

\section{PENDAHULUAN}

Vaksin DNA untuk mencegah infeksi viral nervous necrosis (VNN) pada ikan kerapu telah dibuat dalam dua jenis konstruksi dengan promoter berbeda (Nuraini et al., 2010). Kedua jenis promoter yang digunakan adalah promoter gen $\beta$-aktin ikan medaka Jepang/mBA (Takagi et al., 1994), dan promoter gen keratin ikan flounder Jepang/JfKer (Yazawa et al., 2005). Gen penyandi coat protein (CP) VNN disambungkan dengan masing-masing promoter untuk membuat konstruksi vaksin pmBACP, dan pJfKer-CP (Nuraini et al., 2010). RNA-2 yang merupakan salah satu dari asam inti virus VNN yang menyandikan coat protein (CP) (Chi et al., 2001) diduga sebagai protein infektif dari virus VNN. Protein CP VNN berukuran sekitar 42 kDa (Lin et al., 2007).

Faktor yang menyebabkan ekspresi gen asing dapat tertranslasi menjadi protein salah satunya karena adanya promoter (Alimuddin et al., 2009). Kemampuan promoter dalam mengendalikan ekspresi gen asing yang diintroduksi merupakan salah satu faktor penentu keberhasilan transgenesis, dan juga sangat menentukan efikasi suatu vaksin DNA. Promoter yang sudah digunakan dalam konstruksi vaksin DNA antara lain cytomegalovirus (CMV) dari virus manusia, $\beta$-cardiac myosin heavy chain (MHC) dari kelinci, $\beta$-aktin dari ikan mas (Heppell \& Davis, 2000), dan ikan medaka (Nuryati et al., 2010).
Pengujian produksi protein imunogenik menggunakan embrio ikan lele hasil pemijahan buatan dilakukan dengan pertimbangan kemudahan dalam memperoleh induk ikan matang kelamin dan induksi ovulasi. Keuntungan penggunaan telur ikan sebagai inang dalam pengujian ekspresi protein adalah jumlah telur ikan relatif banyak dapat diperoleh dari satu ekor induk, fertilisasi terjadi secara eksternal memungkinkan introduksi gen asing pengkode protein target, dan embrio ikan dapat dipelihara dalam air tanpa perlu suplemen, karena untuk perkembangan embrio mengandalkan nutrisi yang disediakan oleh kuning telur. Ekspresi transgen (gen target) dimulai pada tahap pertengahan blastula pada embrio ikan (Tsai et al., 1995; Dunham, 2004). $\mathrm{Hal}$ yang sama dilaporkan oleh Morita et al. (2004) yang menggunakan embrio ikan rainbow trout (Oncorhynchus mykiss) untuk mengetahui transient expression atau ekspresi gen dari luteinizing hormone ikan koki ( $\mathrm{gfLH}$ ) yang dikendalikan oleh promoter tertentu.

Pada penelitian ini dilakukan pengukuran tingkat ekspresi protein dan mRNA RNA2 penyandi CP VNN yang dikendalikan oleh dua promoter berbeda, yaitu promoter $\beta$-aktin ikan medaka (mBA) dan keratin ikan flounder Jepang (JfKer). Penelitian ini merupakan tahap awal pengembangan vaksinasi DNA untuk pengendalian infeksi VNN. Pengembangan vaksin DNA VNN diharapkan dapat berguna 
untuk mendukung peningkatan produktivitas dan efisiensi produksi usaha budidaya ikan kerapu.

\section{BAHAN DAN METODE}

\section{Preparasi Vaksin DNA}

Bakteri Escherichia coli $\mathrm{DH} 5 \alpha$ yang mengandung konstruksi vaksin DNA diinokulasi ke dalam media 2 XYT (Nuryati et al., 2010). Bakteri diinkubasi dan dikocok menggunakan shaker dengan kecepatan 250 rpm sekitar $17 \mathrm{jam}$ pada suhu $37^{\circ} \mathrm{C}$. Isolasi plasmid pJfKer-CP dan pmBA-CP dilakukan sesuai metode konvensional (Sambrook \& Russell, 2001), dan illustra plasmidPrep Mini Spin (GE Healthcare) dengan prosedur sesuai manual. Selanjutnya keberadaan pJfKer-CP dan pMBA$\mathrm{CP}$ hasil isolasi dianalisis menggunakan PCR.

\section{Analisis Aktivitas Promoter pada Embrio Ikan Lele}

Embrio ikan lele dumbo diperoleh melalui pemijahan buatan di Balai Besar Pengembangan Budidaya Air Tawar, Sukabumi. Plasmid konstruksi vaksin DNA diinjeksi menggunakan mikromanipulator ke embrio ikan lele fase 1-2 sel untuk memproduksi protein CP VNN. Mikroinjeksi dilakukan mengikuti metode Gusrina et al. (2009). Sebanyak $10 \mu \mathrm{L}$ larutan pJfKer-CP dan pmBA-CP (konsentrasi 50 $\mathrm{ng} / \mu \mathrm{L}$ dengan pelarut $1 \mathrm{M} \mathrm{KCl}$ dimasukkan ke dalam jarum mikroinjeksi, dan kemudian dipasang pada mikromanipulator. Embrio ikan diatur dalam plate agarosa (konsentrasi $2 \%$ ). Proses mikroinjeksi dilakukan di bawah mikroskop dengan menginjeksikan larutan DNA ke dalam blastodisk embrio sebanyak 10 $\mu \mathrm{L}$.

\section{Analisis Ekspresi Protein CP VNN}

\section{Isolasi Protein CP VNN}

Embrio ikan lele yang telah diinjeksi dengan plasmid pJfKer-CP dan pmBA-CP dikoleksi pada jam ke-6, 8, 10, 12, 14, dan 16 pasca mikroinjeksi. Embrio-embrio sebanyak 30 butir digerus dan dibuat suspensi $10 \%$ dengan PBS $(\mathrm{pH} 7,4)$. Suspensi disentrifugasi pada kecepatan $5.000 \mathrm{~g}$ selama lima menit. Selanjutnya supernatan dipindahkan ke tube baru dan diukur konsentrasi proteinnya menggunakan metode Bradford (Bradford, 1976) dan spektrofotometer pada panjang gelombang $595 \mathrm{~nm}$.

\section{Deteksi Protein CP VNN dengan Metode SDS-PAGE dan Western Blotting}

Sebanyak $20 \mu \mathrm{L}$ supernatan embrio ikan lele dengan konsentrasi $10 \mu \mathrm{g} / \mathrm{mL}$ dari masingmasing waktu pengambilan ditambahkan dengan $5 \mu \mathrm{L}$ buffer sampel dan ditangas pada suhu $95^{\circ} \mathrm{C}$ selama dua menit. Selanjutnya sampel dimasukkan ke dalam sumur gel elektroforesis yang terdiri atas gel pengumpul (konsentrasi 4\%) dan gel pemisah (konsentrasi 7,5\%-1 7,5\%). Gel dilarikan dalam alat elektroforesis pada kuat medan listrik 160 Volt selama 60 menit. Setelah elektroforesis berakhir, gel direndam dalam pewarna coomassie brilian blue R-250 selama tiga jam pada suhu ruang sambil diagitasi perlahan. Pewarna yang tidak terikat pada protein dihilangkan dengan merendam gel pada larutan pemucat metanol $25 \%$ dan asam asetat $12 \%$ sampai gel berwarna bening dan pita-pita protein yang terbentuk terlihat jelas.

Protein telur yang telah dielektroforesis dengan teknik SDS-PAGE dipindahkan ke membran nitroselulosa menggunakan Transblot (Biorad) dengan prosedur sesuai manual. Membran nitroselulose diinkubasi dalam 5\% larutan blocking selama 60 menit kemudian direndam dalam larutan serum kelinci anti-VNN (pengenceran 1:50), serta diinkubasikan selama semalam dan diagitasi perlahan. Membran dicuci dengan $0,1 \%$ PBS Tween, selanjutnya diinkubasi dengan antibodi sekunder anti-rabbit peroksidase pada pengenceran 1:5.000 selama satu jam dan dicuci kembali dengan $0,1 \%$ PBS Tween. Membran diinkubasi kembali dengan substrat yang mengandung AP Buffer $20 \mathrm{~mL}$, NBT $66 \mu \mathrm{L}$, BCIP $132 \mu \mathrm{L}$ selama 20 menit dan deteksi dilakukan secara visual. Reaksi antara antibodi primer dengan antibodi sekunder memberikan hasil pewarnaan yang selanjutnya didokumentasikan.

\section{Vaksinasi}

Ikan kerapu tikus berukuran $5 \mathrm{~cm}$ dengan bobot 4-5 g/ekor dan bebas VNN diperoleh dari Balai Budidaya Air Payau, Situbondo. Ikan diaklimatisasi selama satu hari sebelum pelaksanaan vaksinasi. Sebanyak 48 ekor ikan kerapu dibagi ke dalam empat kelompok, masing-masing 12 ekor dengan dua ulangan. Ikan divaksin dengan dosis berbeda, yaitu 7,5; 10,$0 ; 12,5 \mu \mathrm{g} / \mathrm{mL}$; dan ikan kontrol tidak divaksinasi. Rancangan vaksinasi dan pengamatan ekspresi mRNA CP disajikan pada Tabel 1 . 
Tabel 1. Rancangan vaksinasi dan waktu pengambilan sampel

Table 1. The design of the vaccination and sampling

\begin{tabular}{|c|c|c|c|}
\hline \multirow{2}{*}{$\begin{array}{c}\text { Dosis vaksinasi } \\
\text { Vaccination dose } \\
(\mu \mathrm{g} / \mathrm{mL})\end{array}$} & \multicolumn{3}{|c|}{$\begin{array}{l}\text { Wakt u pengambilan sampel ikan setelah vaksinasi (jam) } \\
\text { Fish sampling time after vaccination (hours) }\end{array}$} \\
\hline & 6 & 12 & 24 \\
\hline 7.5 & 2 ekor (fishes) & 2 ekor (fishes) & 2 ekor (fishes) \\
\hline 10 & 2 ekor (fishes) & 2 ekor (fishes) & 2 ekor (fishes) \\
\hline 12.5 & 2 ekor (fishes) & 2 ekor (fishes) & 2 ekor (fishes) \\
\hline Kontrol (Control) & 2 ekor (fishes) & 2 ekor (fishes) & 2 ekor (fishes) \\
\hline
\end{tabular}

\section{Analisis Ekspresi mRNA CP}

\section{Isolasi RNA Total}

Jaringan ikan sebanyak 25-75 mg digerus dalam $1 \mathrm{~mL}$ TRIzol ${ }^{\circledR}$, dengan prosedur sesuai manual. Supernatan dibuang dan pelet RNA dikering-anginkan, selanjutnya pelet dicairkan dengan 50-100 $\mu \mathrm{L}$ double destillated water.

\section{Deteksi Ekspresi mRNA CP}

Tingkat ekspresi mRNA CP dianalisis menggunakan metode reverse transcriptase PCR (RT-PCR). Reaksi dan program PCR yang digunakan mengikuti metode Nuraini et al. (2010). Amplifikasi PCR dilakukan menggunakan primer Forward 5-ATGGTACGCAAA GGTGAGAAGAAATTG-3 dan Primer Reverse 5CTGGGAGATTCTCGACATACC-3 dengan ukuran fragmen DNA target PCR 195 bp. Sebagai kontrol internal digunakan gen $\beta$-aktin kerapu tikus dengan urutan basa Forward 5ATGGTACGCAAAGGTGAGAAGAAATTG-3 dan Reverse 5-CTGGGAGATTCTCGACATACC-3. Hasil PCR diseparasi menggunakan elektroforesis pada gel agarosa $1 \%$.

\section{HASIL DAN BAHASAN}

\section{Aktivitas Promoter pada Embrio Ikan Lele}

Supernatan embrio ikan lele dari masingmasing waktu koleksi memiliki konsentrasi berbeda-beda. Hasil isolasi protein asal embrio ikan berkisar antara 8,48-1 7,77 $\mu \mathrm{g} /$ embrio. Konsentrasi protein yang dihasilkan menunjukkan nilai yang semakin meningkat seiring dengan lamanya waktu koleksi (Tabel 2). Konsentrasi protein hasil koleksi pada jam ke12 dari perlakuan mikroinjeksi plasmid pmBA$\mathrm{CP}$ lebih rendah dan mengalami penurunan dibandingkan pada jam koleksi berikutnya. Hal tersebut disebabkan adanya kematian embrio sebelum dilakukan ekstraksi yang diduga terjadi kerusakan sel akibat mikroinjeksi. Risiko penggunakan metode mikroinjeksi, antara lain bila jarum mikro terlalu masuk ke dalam telur ikan dan mengenai kantong kuning telur yang dapat menyebabkan kerusakan dan kematian embrio ikan.

Konsentrasi protein dari embrio ikan yang diinjeksi plasmid pJfKer-CP dengan promoter keratin lebih rendah dibandingkan dengan promoter $\beta$-aktin. Perbedaan konsentrasi protein tersebut dapat disebabkan perbedaan aktivitas promoter yang mengendalikan proses transkripsi (Alimuddin et al., 2009). Perbedaan aktivitas promoter eksogen dipengaruhi oleh kesesuaian antara cis-acting yang ada dalam sekuen promoter dan trans-acting ikan target (Dunham, 2004). Sifat promoter $\beta$ aktin terkait aktivitas elemen-elemennya yaitu house-keeping (aktif kapan saja) dan ubiquitous (Hackett, 1993); serta constitutive (aktif tanpa stimulan dari luar seperti suhu dan hormon) (Volckaert et al., 1994). Menurut Yazawa et al. (2005), promoter keratin memiliki aktivitas terkuat pada jaringan epitel dan hati saat diujicobakan pada ikan zebra. Gong et al. (2002) menyatakan bahwa promoter keratin digunakan dalam teknologi transgenesis terkait dengan sistem imunitas karena efektivitasnya tinggi di jaringan kulit. Dengan demikian, efektivitas promoter dapat memengaruhi aktivitas vaksin DNA pada ikan sesuai pendapat Hackett (1993) bahwa promoter memengaruhi transkripsi dalam segmen DNA yang sama di mana promoter tersebut berada. Selanjutnya Glick \& Pasternak (2003) menambahkan bahwa sekuen tersebut dikenali oleh RNA polimerase yang kemudian menempel dan mengendalikan proses transkripsi. 
Tabel 2. Konsentrasi protein dari embrio ikan lele setelah mikroinjeksi dengan vaksin DNA VNN dengan konstruksi berbeda

Table 2. The protein concentration of catfish embryos after microinjection with DNA vaccines VNN with different construction

\begin{tabular}{|c|c|c|}
\hline \multirow{2}{*}{$\begin{array}{l}\text { Wakt u koleksi } \\
\text { Collection time } \\
\text { jam (hours) }\end{array}$} & \multicolumn{2}{|c|}{$\begin{array}{c}\text { Konsent rasi protein }(\mu \mathrm{g} / \mathrm{embrio}) \\
\text { Concentration of protein }(\mu \mathrm{g} / \mathrm{em} \text { bryo })\end{array}$} \\
\hline & $\begin{array}{c}\text { Plasmid DNA VNN } \\
\text { promoter } \beta \text {-akt in } \\
\text { Plasmid of DNA VNN } \\
\text { B-act in promoter }\end{array}$ & $\begin{array}{l}\text { Plasmid DNA VNN } \\
\text { promoter kerat in } \\
\text { Plasmid of DNA VNN } \\
\text { kerat in promoter }\end{array}$ \\
\hline 6 & 8.48 & 13.13 \\
\hline 8 & 16.48 & 12.75 \\
\hline 10 & 17.02 & 14.48 \\
\hline 12 & 9.12 & 16.37 \\
\hline 14 & 16.68 & 15.91 \\
\hline 16 & 17.77 & 15.53 \\
\hline
\end{tabular}

\section{Ekspresi Protein CP dari Virus VNN}

Pada produksi antibodi poliklonal antiVNN, kelinci diimunisasi dengan suspensi virus VNN sebanyak tiga kali dengan rute subcutan (SC). Hasil menunjukkan bahwa Ab anti-VNN pada kelinci mampu diinduksi oleh antigen VNN yang disuntikan ke kelinci dengan dosis 33,5 $\mu \mathrm{g} /$ bobot badan. Hal tersebut sesuai penelitian Goidl et al. (1968) bahwa Ab poliklonal pada kelinci dapat diinduksi dengan penyuntikan antigen sebanyak $25-50 \mu \mathrm{g} / \mathrm{kg}$ bobot badan. Deteksi antibodi anti-VNN dalam serum dilakukan menggunakan uji presipitasi (agar gel presipitation test) menunjukkan hasil dengan terbentuknya garis presipitasi antara sumur antigen dengan serum yang diuji. Hal ini sesuai dengan pengujian oleh Andriyani (2012).

Berdasarkan hasil SDS-PAGE untuk deteksi dan karakterisasi protein CP (coat protein) vaksin DNA yang diinsersikan dalam gen embrio ikan lele, diperoleh profil pita protein CP berukuran sekitar $42 \mathrm{kDa}$ (ditunjukkan dengan tanda kepala panah) terdapat pada sampel yang diinjeksi dengan vaksin DNA (kolom No. 1-4, dan 6-9), sedangkan pada supernatan embrio ikan lele yang tidak divaksin (kolom No. 5) tidak ditemukan pita protein tersebut (Gambar 1A).

Keberadaan protein virus VNN yang terekspresi di embrio ikan lele ini dikonfirmasi dengan Western blot menggunakan antibodi poliklonal anti-VNN menunjukkan hasil positif terhadap protein CP dari virus VNN (Gambar 1B). Pada uji imunokimia dengan Western blot, protein CP memberikan reaksi positif karena protein $\mathrm{CP}$ difusikan dengan protein pengikat VNN. Reaksi positif yang terjadi sebagai respons protein CP terhadap antibodinya (Gambar 1B), spesifik protein CP terdeteksi pada ukuran sekitar $42 \mathrm{kDa}$. Ekspresi spesifik protein CP pada embrio ikan lele mulai terlihat pada fase blastula (jam ke- 6 setelah fertilisasi) hingga fase akhir gastrula (12 jam setelah fertilisasi). Hal ini sejalan dengan yang dilaporkan oleh Tsai et al. (1995) dan Dunham (2004) bahwa ekspresi gen eksogen dapat dideteksi pada fase blastula.

Ekspresi protein CP pada embrio ikan lele yang diinjeksi konstruksi pmBA-CP lebih tinggi daripada pJfKer-CP. Ekspresi protein yang terdeteksi merupakan gambaran tingkat ekspesi gen yang diinjeksikan pada embrio ikan lele. Menurut lyengar et al. (1996), tingkat ekspresi gen asing yang tinggi setelah fase mid-blastula hingga fase gastrula, merupakan hasil dari akumulasi DNA yang diinjeksikan, akibat peningkatan replikasi selama fase pembelahan (cleavage) dan akumulasi dari RNA polymerase II yang menyebabkan dimulainya transkripsi pada mid-blastula transition. Hal tersebut menunjukkan bahwa ekspresi protein $\mathrm{CP}$ yang terjadi dipengaruhi proses transkripsi pada sel embrio ikan lele. 


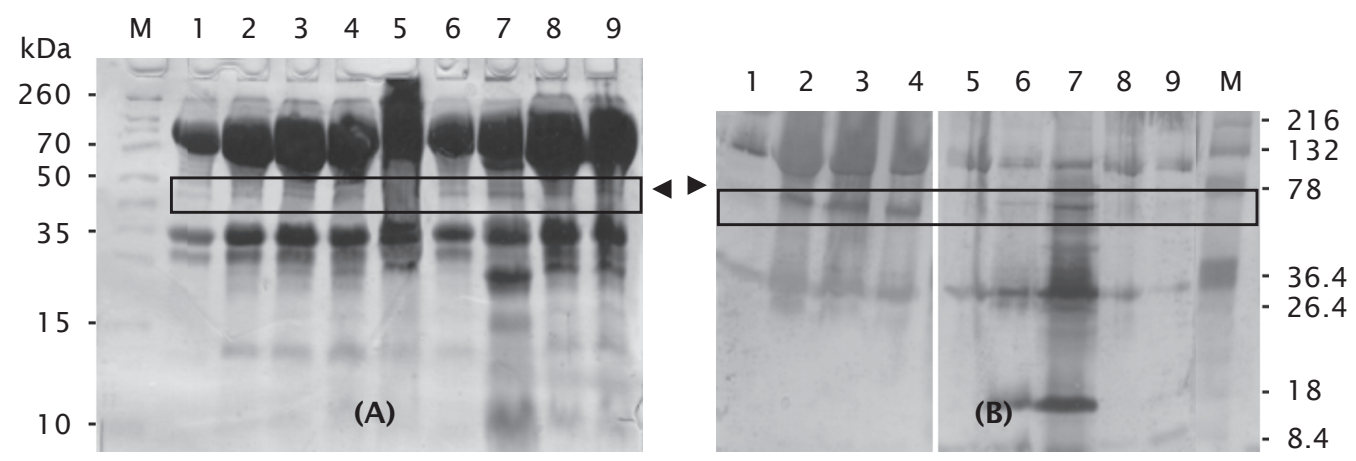

Gambar 1. Analisis SDS-PAGE (A) dan Western blot (B) protein dari embrio ikan lele yang diinjeksi dengan pmBA-CP dan pJfKer-CP. Western blot dilakukan menggunakan antibodi anti VNN dari kelinci. $\mathrm{M}=$ Marker protein; 1 = Protein pmBA-PCV 6 jam; 2 = Protein pmBA-PCV 8 jam; 3 = Protein pmBA-PCV 10 jam; 4 = pmBA-PCV 12 jam; 5 = Protein embrio ikan lele non-induksi 10 jam; 6 = Protein pJfKer-PCV 6 jam; 7 = Protein pJfKer-PCV 8 jam; $8=$ Protein pJfKer-PCV 10 jam; 9 = Protein pJfKer-PCV 12 jam. Tanda kepala panah menunjukkan posisi protein CP VNN

Figure 1. Analysis SDS-PAGE $(A)$ and Western blot (B) of protein's catfish embryos after injected with pmBA-CP and $p J$ fKer-CP. Western blot performed antibodies rabbit anti VNN. $M=$ Protein marker; 1 = Protein PCV pmBA 6 hours; $2=$ Protein PCV pmBA 8 hours; $3=$ Protein PCV pmBA 10 hours; $4=P C V$ pmBA 12 hours; $5=$ Embryo's protein catfish non induction 10 hours; 6 = Protein PCV pJfKer 6 hours; $7=$ Protein PCV pJfKer 8 hours; $8=$ Protein PCV pJfKer 10 hours; $9=$ Protein PCV pJfKer 12 hours. Sign arrowheads indicate the position of the CP protein VNN

\section{Vaksinasi dan Ekspresi mRNA CP pada Ikan Kerapu}

Tingkat produksi protein $\mathrm{CP}$ dari vaksin DNA menggunakan konstruksi pmBA-CP lebih tinggi daripada pJfKer-CP pada hasil uji Western blot, maka dalam penelitian selanjutnya digunakan pmBA-CP. Uji ekspresi mRNA CP diawali dengan deteksi keberadaan pmBA-CP pada jaringan otot ikan yang diinjeksi pmBACP dengan teknik PCR. Hasil menunjukkan bahwa DNA pmBA-CP terdapat pada jaringan otot ikan kerapu yang diinjeksi dengan pmBACP dosis 12,5 $\mu \mathrm{g}$ /ekor pada 6 dan 24 jam pascainjeksi. Produk PCR menunjukkan pita DNA pada 1.000 bp sesuai ukuran plasmid (Gambar tidak ditampilkan). Hal ini menunjukkan bahwa DNA pmBA-CP terdapat dalam jaringan otot ikan kerapu. Alimuddin et al. (2009) menjelaskan bahwa metode injeksi langsung ke otot daging biasanya memerlukan tahap lanjutan seperti RT-PCR untuk melihat tingkat transkripsi RNA. Hasil RT-PCR menunjukkan bahwa ekspresi mRNA CP VNN terdeteksi pada ikan yang divaksinasi dengan pmBA-CP dosis 12,5 $\mu \mathrm{g}$ /ekor pada saat 24 jam pasca injeksi (Gambar 2). Kemunculan ekspresi mRNA CP VNN lebih cepat dibandingkan pe- nelitian Zheng et al. (2006) yang mendeteksi keberadaan mRNA vaksin DNA lympocystis disease virus (LCDV) pada otot bekas suntikan, otot berseberangan dengan bekas penyuntikan, usus, insang, limfa, ginjal depan hati, dan gonad ikan flounder pada hari ke-7 pascavaksinasi.

Analisis transkripsi mRNA menggunakan metode RT-PCR menunjukkan bahwa vaksin DNA pmBA-CP mampu ditranskripsikan di dalam sel somatik ikan kerapu dan selanjutnya disintesis menjadi protein antigenik CP VNN. Perbedaan tingkat ekspresi mRNA CP VNN pada ikan kerapu dibandingkan dengan ekspresi protein CP pada embrio ikan lele (pada enam jam pasca vaksinasi) diduga dipengaruhi oleh promotor mBA yang mempunyai kesesuaian yang lebih tinggi pada ikan lele dibandingkan ikan kerapu. Hal tersebut sesuai pendapat Dunham (2004) bahwa berbagai macam promoter dapat aktif pada sel ikan walaupun bukan dari ikan yang homolog, tetapi akan memengaruhi tingkat ekspresi gen karena adanya interaksi elemen cis-regulator pada promoter dan trans-regulator pada inang.

Ekspresi mRNA CP masih terdeteksi hingga dua minggu pasca injeksi (Gambar 2B). Hal ini 
$\begin{array}{lllllllllllll}M & 1 & 2 & 3 & 4 & 5 & 6 & 7 & 8 & 9 & 1 & 0 & 11\end{array}$

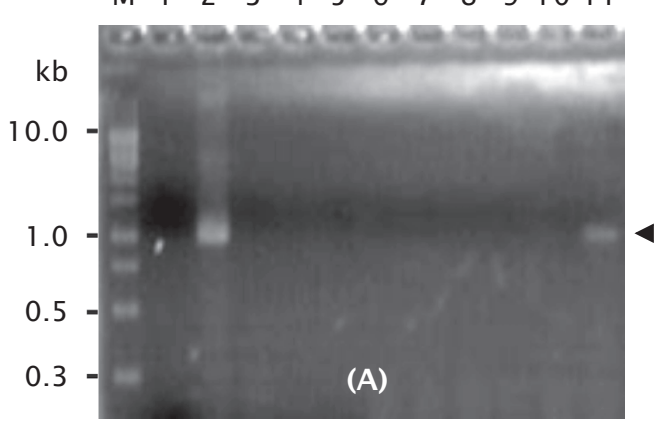

$\mathrm{kb}$

1.0

0.5

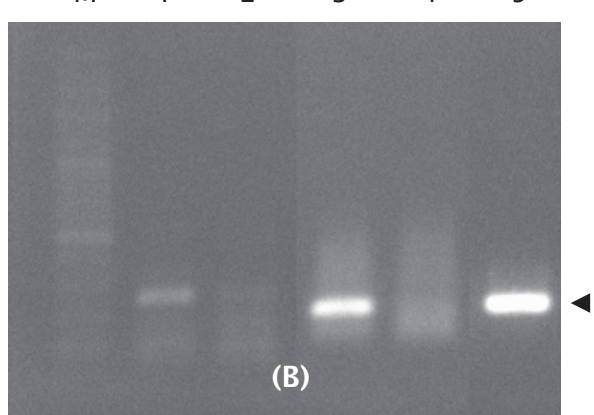

Gambar 2. Deteksi ekspresi mRNA CP VNN dalam tubuh ikan yang telah diinjeksi dengan vaksin DNA dengan dosis dan waktu pengambilan sampel berbeda (A). M = Marker DN; $1=$ Kontrol negatif; 2 = Kontrol positif; $3=6$ jam-7,5 $\mu \mathrm{g} /$ ekor; $4=6$ jam- $10 \mu \mathrm{g} ; 5=6$ jam$12,5 \mu \mathrm{g} ; 6=12$ jam-7,5 $\mu \mathrm{g} ; 7=12$ jam-10 $\mathrm{jg} ; 8=12$ jam- $12,5 \mu \mathrm{g} ; 9=24$ jam-7,5 $\mu \mathrm{g} ; 10$

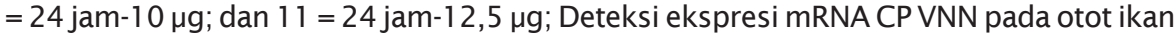
yang telah diinjeksi dengan vaksin DNA, dengan metode PCR (B). M = Marker DNA; $1=$ $\beta$-aktin dari otot (D1); 2 = $\beta$-aktin otot (D14); $3=$ CP-VNN (D1); 4 = CP-VNN (D14); $5=$ Plasmid. Tanda kepala panah menunjukkan posisi fragmen mRNA VNN.

Figure 2. Detection of of CP VNN mRNA expression in fish after injected by DNA vaccine in different doses and sampling time (A). $M=$ DNA Marker; 1 = Negative control; $2=$ Positive control; $3=6$ hours-7.5 $\mathrm{mg} /$ fishes; 4 = 6-hour-10 $\mathrm{\mu g} /$ fishes; $5=6$ hours- 12.5 $\mathrm{gg} /$ fishes; $6=12$-hour-7.5 $\mathrm{\mu g} /$ fishes; $7=12$ hours- $10 \mu \mathrm{g} /$ fishes; $8=12$ hours- $12.5 \mu \mathrm{g} /$ fishes; $9=24$ hours-7.5 $\mathrm{\mu g} /$ fishes; $10=24$-hour- $10 \mu \mathrm{g} /$ fishes; and $11=24$ hours- 12.5 $\mu \mathrm{g} /$ fishes; Detection of CP VNN $m R N A$ expression in fish muscle after injected the DNA vaccine, with the PCR method (B). $M=$ DNA Marker; 1 = Muscle actin (D1); $2=$ Muscle actin (D14); 3 = CP-VNN (D1); 4 = CP-VNN (D14); 5 = Plasmid. Arrowheads indicate the position of the mRNA VNN

menunjukkan bahwa DNA pmBA-CP dapat bertahan dan promoter $\beta$-aktin ikan medaka aktif pada otot sampai dua minggu setelah injeksi. Hal ini juga telah dilaporkan oleh Nuryati et al. (2010) bahwa analisis RT-PCR ikan mas yang diinjeksi pAct-GP25 menunjukkan adanya ekspresi gen pada hari ke-14 di semua jaringan yang diamati. Perbedaan tingkat ekspresi antara jam 24 (Gambar 2A) dan hari ke-14 (Gambar 2B) diduga berhubungan dengan sensitivitas primer yang dipakai dan ukuran fragmen DNA target. Pada Gambar 2A, panjang DNA target PCR adalah $1 \mathrm{~kb}$, sedangkan pada Gambar 2B sekitar 0,19 kb. Menurut Nuryati et al. (2010), secara umum target produk PCR yang berukuran lebih kecil akan lebih mudah diamplifikasi dibandingkan dengan DNA yang lebih besar. Hasil dari deteksi ekspresi gen menunjukkan bahwa promoter $\beta$-aktin ikan medaka bersifat aktif mengekspresikan gen CP VNN.

\section{KESIMPULAN}

Tingkat ekspresi protein dan mRNA RNA2 penyandi coat protein $(\mathrm{CP})$ virus viral nervous necrosis (VNN) yang dikendalikan promoter $\beta$ aktin ikan medaka (mBA) lebih tinggi dibandingkan keratin ikan flounder Jepang (JfKer).

\section{UCAPAN TERIMA KASIH}

Terima kasih kami sampaikan kepada Balai Besar Pengembangan Budidaya Air Tawar, Sukabumi yang telah memberikan fasilitas sehingga terlaksana penelitian ini, Program Pendidikan Gelar Tugas Belajar 2012 Pusat Pendidikan Kementerian Kelautan dan Perikanan dan Balai Budidaya Air Payau, Situbondo yang telah membiayai penelitian ini, serta semua pihak yang telah banyak membantu terselesainya laporan penelitian ini.

\section{DAFTAR ACUAN}

Alimuddin, Lola, I.P., Ath-thar, M.H.F., Chairul, M., Carman, O., \& Sumantadinata, K. 2009. Aktivitas promoter $\beta$-aktin ikan medaka Jepang (Oryzias latipes) pada ikan mas (Cyprinus carpio). J. Natur. Indonesia, 11 : 70-77. 
Andriyani, W.M. 2012. Uji kemampuan kandidat vaksin DNA viral nervous necrosis dalam menginduksi antibodi pada ikan kerapu tikus (Cromileptes altivelis). Tesis. Institut Pertanian Bogor. Bogor, 65 hlm.

Bradford, M.M. 1976. A rapid and sensitive method for the quantitation of microgram quantities of protein utilizing the principle of protein-dye binding. Analytical Biochemistry, 72: 248-254.

Chi, S.C., Lo, B.J., \& Lin, S.C. 2001 . Characterization of grouper nervous necrosis virus (GNNV). J. Fish Dis., 24: 3-13.

Dunham, R.A. 2004. Aquaculture and fisheries biotechnology: genetic approaches. Cambridge. CABI Publishing, 367 pp.

Glick, B.R. \& Pasternak, J.J. 2003. Molecular biotechnology: principles and application of recombinant DNA. $3^{\text {rd }}$ Ed. Washington D.C. ASM Press. 784 pp.

Goidl, E., Paul, W.E., Siskind, G.W., \& Benacerraf, B. 1968. The effect of antigen dose and time after immunization on the amount and affinity of anti-hapten antibody. J. Immunol., 100(2): 371-375.

Gong, Z., Wan, H., Ju, B., He, J., Wang, X., \& Yan, T. 2002. Generation of living color transgenic fish. In Shimizu, N., Aoki, T., Hirono, I., \& Takashima, F. Aquatic Genomics. Steps Toward a Great Future. Springer-Verlag. New York, p. 329-339.

Gusrina, Alimuddin, Sumantadinata, K., \& Widyastuti, U. 2009. Transfer gen penyandi hormon pertumbuhan ikan nila (Oreochromis niloticus) pada ikan lele (Clarias sp.) dengan metode mikroinjeksi. J. Ris. Akuakultur, 4(3): 333-340.

Hackett, P.B. 1993. The molecular biology of transgenic fish. In Hocachka \& Mommesen (Eds.). Biochem. Mol. Biol. Fish., 2: 218-221.

Heppell, J. \& Davis, H.L. 2000. Application of DNA vaccine technology to aquaculture. Adv. Drug. Deliv. Rev., 43: 29-43.

Iyengar, A., Muller, F., \& Maclean, N. 1996. Regulation and expression of transgenes fisha review. Transgenic Research, 5: 147-166.

Lin, C.C., Jhon, H.Y.L., Ming, S.C., \& Huey, L.Y. 2007. An oral nervous necrosis virus vaccine that induced protective immunity in larvae of grouper Epinephelus coioides. Aquaculture, 268: 265-273.
Morita, T., Yoshizaki, G., Kobayashi, M., Watabe, S., \& Takeuchi, T. 2004. Fish eggs as bioreactors: the production of bioactive luteinizing hormone in transgenic trout embryos. Transgenic Research, 13: 551-557.

Nuraini, Y.L., Subyakto, S., Triastutik, G., Fatmawati, \& Alimuddin. 2010. Pembuatan vaksin DNA untuk virus VNN ikan kerapu dan uji ekspresinya secara in vivo. Balai Budidaya Air Payau, Situbondo. $18 \mathrm{hlm}$.

Nuryati, S., Alimuddin, Sukenda, Soejoedono, R.D., Santika, A., Pasaribu, F.H., \& Sumantadinata, K. 2010. Construction of a DNA vaccine using glycoprotein- 25 and its expression towards increasing survival rate of KHV-infected common carp (Cyprinus carpio). J. Natur Indonesia, 13: 47-52.

Sambrook, J. \& Russell, D.W. 2001. Molecular cloning a laboratory manual. Third Edition. www.MolecularCloning.com. Cold Spring Harbor Laboratory Press. New York, 749 pp.

Takagi, S., Sasado, G., Tamiya, G., Ozato, K., Wakamatsu, Y., Takeshita, A., \& Kimura, M. 1994. An efficient expression vector for transgenic medaka construction. Mol. Mar. Biol. Biotechnol., 3: 192-199.

Tsai, H.J., Wang, S.H., Inoue, K., Takagi, S., Kimura, M., Wakamatsu, Y., \& Ozato, K. 1995. Initiation of the trans-genic lacZ gene expression in medaka (Oryzias latipes) embryos. Mol. Mar. Biol. Biotechnol., 4: 1-9.

Volckaert, F.A., Hellemans, B.A., Galbusera, P., \& Ollevier, F. 1994. Replication, expression and fate of foreign DNA during embryonic and larva development of the Africa catfish Clarias gariepinus. Mol. Mar. Biol. Biotechnol., 3(2): 57-69.

Yazawa, R., Hirono, I., \& Aoki, T. 2005. Characterization of promoter activities of four different Japanese flounder promoters in transgenic zebrafish. Marine Biotechnology, 7: 625-633.

Zheng, F.R., Sun, X.Q., Liu, H.Z., \& Zhang, J.X. 2006. Study on distribution and expression of a DNA vaccine againts lymphocystis disease virus in Japanese flounder. Aquaculture, 261: 1,128-1,134. 